\title{
Evaluation of influenza-specific humoral response by microbead array analysis
}

\author{
Yoav Keynan MD, Tavis Bodnarchuk MD, Stephen Wayne BSc, Yan Li PhD, Keith R Fowke PhD
}

Y Keynan, T Bodnarchuk, S Wayne, Y Li, KR Fowke. Evaluation of influenza-specific humoral response by microbead array analysis. Can J Infect Dis Med Microbiol 2011;22(1):25-29.

RATIONALE: Quantitation and determination of antigen specificity of systemic and mucosal immune responses to influenza vaccination is beneficial for future vaccine development. Previous methods to acquire this information were costly, time consuming and sample exhaustive. The benefits of suspension microbead array (MBA) analysis are numerous. The multiplex capabilities of the system conserve time, money and sample, while generating statistically powerful data. OBJECTIVE: To demonstrate the use of the assay by comparing the humoral influenza-specific responses of two cohorts from two countries that differed in circulating influenza strains and rates of influenza vaccination.

METHODS: Influenza hemagglutinin (HA) from different strains were coated on microbeads and incubated with serum samples to capture immunoglobulin ( $\mathrm{Ig}) \mathrm{A}_{1}$ and $\mathrm{IgG}_{1}$ host antibodies.

RESULTS: Statistically significant differences in $\operatorname{IgA}_{1}$ and $\operatorname{IgG}_{1}$ exist between the serum samples from Winnipeg (Manitoba) donors and those from Kenyan (Africa) donors. Data were compared using MannWhitney nonparametric tests. The Winnipeg donors had higher mean fluorescence intensity values, with significant $\mathrm{P}$ values for anti-HA $\operatorname{Ig} \mathrm{A}_{1}$ to $\mathrm{A} / \mathrm{W}_{\text {yoming/3/2003 }}(\mathrm{P}=0.044), \mathrm{A} /$ Vietnam/1203/2004 $(\mathrm{P}=0.0179), \mathrm{A} / \mathrm{New}$ Caledonia/20/99 $(\mathrm{P}<0.0001)$ and $\mathrm{B} /$ Tokyo/53/99 $(\mathrm{P}=0.0002)$. No differences were seen between the groups in their response to $\mathrm{B} / \mathrm{Jilin} / 20 / 2003$. The Winnipeg donors had higher mean fluorescence intensity values, with significant $\mathrm{P}$ values for anti-HA $\mathrm{IgG}_{1}$ to $\mathrm{A} / \mathrm{W}_{\text {yoming/3/2003 }}(\mathrm{P}=0.0135), \mathrm{B} /$ Tokyo/53/99 $(\mathrm{P}=0.006)$ and $\mathrm{B} / \mathrm{Jilin} 20 / 2003(\mathrm{P}=0.026)$.

CONCLUSION: Influenza-specific $\operatorname{Ig} A_{1}$ and $\operatorname{IgG}_{1}$ antibodies were successfully detected using MBA technology. A significant difference in antibody response was observed between Winnipeg and Kenyan donor serums. MBA analysis is a relatively quick and cost-effective method for serum antibody analysis. The potential to simultaneously assay small sample volumes for a multitude of antigens makes this method invaluable for future vaccine response monitoring.

Key Words: Hemagglutinin; Immunoglobulin; Influenza; Microbead array

\section{Évaluation de la réponse humorale spécifique au virus de la grippe par technologie des microbilles}

JUSTIFICATION : La quantification et la détermination de la spécificité antigénique des réactions immunitaires systémiques et muqueuses au vaccin antigrippal servent à l'élaboration des futurs vaccins. Les méthodes précédentes d'acquisition de ce type de données étaient coûteuses, fastidieuses et exigeaient de nombreux d'échantillons. La technologie des microbilles comporte de nombreux avantages : tout en générant des données puissantes sur le plan statistique, les capacités multiplex du système permettent d'épargner temps et argent, en plus d'exiger moins d'échantillons.

OBJECTIF : Démontrer l'utilisation de cette technologie en comparant les réponses humorales spécifiques au virus de la grippe dans deux cohortes provenant de deux pays où les souches grippales circulantes, de même que les taux de vaccination antigrippale, étaient différents.

MÉTHODES : L’hémagglutinine (HA) de différentes souches du virus de la grippe a été appliquée à la surface de microbilles et mise en incubation avec des spécimens sérologiques afin de capter les immunoglobulines $(\mathrm{Ig}) \mathrm{A}_{1}$ et $\mathrm{IgG}_{1}$ de l'hôte.

RÉSULTATS : On note des différences statistiquement significatives entre les $\mathrm{IgA}_{1}$ et $\mathrm{IgG}_{1}$ des échantillons sérologiques provenant de donneurs de Winnipeg (Manitoba) et de donneurs kényans (Afrique). Les données ont été comparées à l'aide de tests non paramétriques de Mann-Whitney. Les donneurs de Winnipeg présentaient des valeurs plus élevées en termes d'intensité moyenne à la fluorescence, avec des valeurs $\mathrm{p}$ significatives pour l'anti-IgA dirigécontre $\mathrm{A} /$ Wyoming/3/2003 ( $\mathrm{p}=0,044)$, A/Vietnam/1203/2004 $(\mathrm{p}=0,0179), \mathrm{A} / \mathrm{New}$ Caledonia/20/99 $(\mathrm{p}=0,0001)$ et $\mathrm{B} /$ Tokyo/53/99 $(\mathrm{p}=$ 0,0002 ). Aucune différence n'a été observée entre les groupes quant à leur réponse à $\mathrm{B} / \mathrm{J} \mathrm{ilin} / 20 / 2003$. Les donneurs de Winnipeg ont présenté des valeurs plus élevées en termes d'intensité moyenne à la fluorescence, avec des valeurs $\mathrm{p}$ significatives pour l'anti-IgG $\mathrm{I}_{1}$ dirigé contre $\mathrm{A} / \mathrm{W}_{\text {yoming/3/2003 }}(\mathrm{p}=$ 0,0135), B/Tokyo/53/99 ( $p=0,006)$ et $B / J i l i n 20 / 2003(p=0,026)$.

CONCLUSION : Les anticorps $\operatorname{IgA}_{1}$ et $\mathrm{IgG}_{1}$ spécifiques au virus de la grippe ont été détectés avec succès à l'aide de la technologie des microbilles. Les auteurs ont constaté une réponse immunitaire significativement différente entre les sérums de donneurs de Winnipeg et du Kenya. La technologie des microbilles est une méthode relativement rapide et économique d'analyse des anticorps sériques. La possibilité de tester simultanément de petits volumes d'échantillons pour une multitude d'antigènes donne à cette méthode une valeur inestimable pour la surveillance de la réponse aux vaccinations futures.

nfluenza viruses are the only members of the family Orthomyxoviridae;
they are transmitted by respiratory droplets and are capable of causing
seasonal infections and epidemics $(1,2)$. These viruses have a segmented
(typically eight units) single-stranded RNA genome, with RNA seg-
ments of 890 to 2341 nucleotides each, a helical nucleocapsid and an
outer envelope comprised of lipoprotein $(3,4)$. Three influenza virus
groups (groups A, B and C) infect humans and have been characterized

based on antigenic differences in internal proteins - nucleoprotein and matrix protein (3-5). These internal proteins, along with a viral replication protein (polymerase acidic protein), are highly conserved within groups. The group A influenza virus is further subtyped by the variation of its surface proteins - hemagglutinin (HA) and neuraminidase. These proteins cover the outer membrane and are important virulence factors involved in binding to host cells and viral budding $(3,4)$.

Department of Medical Microbiology, University of Manitoba, Winnipeg, Manitoba

Correspondence: Dr Keith R Fowke, Department of Medical Microbiology, University of Manitoba, 539-730 William Avenue, Winnipeg,

Manitoba R3E OW3. Telephone 204-789-3818,fax 204-789-3926, e-mail fowkekr@cc.umanitoba.ca 


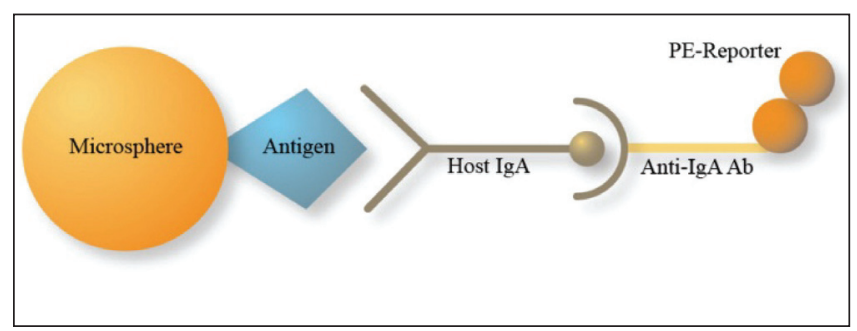

Figure 1) A schematic representation of microbead array. Latex microspheres are coupled to specific antigens (hemagglutinin or p24). Host antigen-specific antibodies $(\mathrm{Ab})$ bind the antigens on the beads. Mouse antihuman immunoglobulin A (IgA) with phycoerythrin (PE) reporter binds any host antigen-specific IgA. PE intensity quantifies host IgA in the sample

Immunity to infection by influenza is conferred by anti-HA antibodies blocking initial viral attachment to host cells. Antibodies to neuraminidase do not prevent infection, but do lessen the severity of disease by limiting viral release from infected host cells $(4,6)$. The antibodies generated are type specific and provide little cross-protection against diseases caused by heterotypic or heterosubtypic strains.

The main response to natural infection is local production of secretory immunoglobulin ( $\mathrm{Ig}$ ) A in the mucosal surfaces of the upper respiratory tract and, to a lesser extent, serum $\operatorname{IgG}, \operatorname{IgA}$ and $\operatorname{IgM}$ (3). One of the problems with current vaccines consisting of killed virus or purified protein particles administered intramuscularly is that the main response to these vaccines is relatively low IgG and $\operatorname{IgA}$ production typically lasting only six months and requiring annual boosters. Another shortcoming of the inactivated vaccines is that the mucosal response at the respiratory tract, the site of viral entry, is limited following these vaccines.

Traditional methods to diagnose influenza infection relied on a fourfold increase in antibody titre, as measured by hemagglutination inhibition assay (HIA), between acute and convalescent serum samples. The HIA is a functional assay that measures the ability of the HA antibody to inhibit the agglutination of sheep red blood cells. Recent evidence (7) suggests that a single serum sample tested within the first week of symptoms can lead to a diagnosis if the antiflu IgA titre is high. Normally, the antiflu IgA is short lived, so its presence indicates recent infection (primary or secondary) (7)

Bead-based flow cytometry can be used to detect antibodies to multiple antigens from a single sample. This technique consists of a high throughput method that allows for the quantitation of the immune response to vaccinations that contain more than one antigen, without having to run individual assays for each antigen (8). The technology is based on 5.5 micron polysterene microspheres that contain a distinct ratio of two luminescent dyes - one red and the other infra-red - creating 100 bead sets with unique identifying spectral addresses. This allows for the simultaneous assay of up to 100 analytes within a single sample as small as $50 \mu \mathrm{L}$, although typical analyses are in the range of 10 to 20 beads. Antigens of interest are coupled to their own specific bead set; several sets are added together to form a master mix, which in turn, is incubated with diluted serum sample to allow complementary antibodies to bind. Biotinylated monoclonal antibodies against human Igs (eg, mouse antihuman $\operatorname{Ig} \mathrm{A}_{1}$ ) are added and bind to any human $\operatorname{Ig} \mathrm{A}_{1}$ attached to antigens on the beads. The beads are passed through a flow cytometer with two lasers. A classification laser detects the colour ratio of the bead and distinguishes the bead set, and thus the antigen bound to it. A second reporter laser detects the intensity of the fluorochrome bound to the monoclonal antibody distinguishing the type and amount of antibody attached to the antigen. This technology allows quantitative and qualitative determination of antibodies present, pre- and postinfluenza viral challenge.

A schematic representation of microbead array (MBA) is shown in Figure 1.

The benefits of MBA analysis are numerous. The multiplex capabilities of the system conserve time, money and sample (8-10). The machine reports the average of 100 individual beads per region, equivalent to 100 ELISA replicates, lending statistical power to the data. To generate the same amount of data using traditional ELISA technology would require heavy investment in time, money and sample (10). The present swine-origin influenza A (H1N1) outbreak has caused 94,512 cases and 429 fatalities as of July 6, 2009 (11), and 10,156 laboratory-confirmed cases leading to 1115 hospitalizations and 45 deaths in Canada as of July 15, 2009 (12). The number of individuals affected by the virus and the distribution within provinces is unknown; seroprevalence is labour intensive and hampered by the lack of a high-throughput method. Assessing the prevalence of antibodies against various influenza strains is of particular importance during an interepidemic phase because the results may identify unexposed populations and guide allocation of vaccine or antiviral therapy. MBA can be used for rapid detection of infection or previous exposure. In the present study, we compared samples from two countries differing in influenza epidemiology and rate of influenza immunization. The distinctly different origin of the samples serves to illustrate the use of multiplex suspension-bead array for detection of antibody response to multiple influenza strains in a high-throughput system requiring low sample quantity. $\operatorname{Ig} \mathrm{A}_{1}$ was surveyed because it is the primary mucosal antibody responsible for neutralization of the virus on challenge and, due to its relatively low yield in serum, to showcase the sensitivity of the assay.

\section{Samples}

\section{METHODS}

Frozen plasma samples from 60 adult donors enrolled in a cohort study in Nairobi (Kenya, Africa) were analyzed for $\operatorname{IgA}_{1}$ and $\mathrm{IgG}_{1}$ antibodies specific to influenza and control antigens. The study population included North American controls (30 individuals from Winnipeg [Manitoba]) and 30 women from Kenya. The study was approved by local ethics boards in Winnipeg and Nairobi.

\section{Materials}

Latex microspheres used in the assay, and assay reagents (wash buffer, assay buffer, reporter antibody and filter well plate) were purchased from Bio-Rad Laboratories (USA). Detection antibody (Mouse Anti-Human IgA $\mathrm{A}_{1}$-Biot clone B3506B4, and $\mathrm{IgG}_{1}$-Biot clone 4e3) was purchased from SouthernBiotech (USA). Recombinant influenza HA proteins (A/Wyoming/3/2003, A/New Caledonia/20/99, A/ Vietnam/1203/2004 and B/Jilin/20/2003) were purchased from Protein Sciences Corporation (USA). Recombinant HA from B/ Tokyo was purchased from Advanced ImmunoChemical Inc (USA). As a positive control, recombinant HIV p24 was purchased from Fitzgerald Industries International (USA).

\section{Microsphere coupling}

Unconjugated, carboxylated microspheres were dispersed with sonication and vortexed for $60 \mathrm{~s}$, and $5 \times 10^{6}$ microspheres $(400 \mu \mathrm{L})$ were dispensed into a $1.5 \mathrm{~mL}$ centrifuge tube and spun down. The pellet was resuspended in $80 \mu \mathrm{L}$ of activation buffer, and sonicated until homogeneous. Ten microlitres of Sulfo-NHS solution (10 mg SulfoNHS per $2 \mathrm{~mL}$ activation buffer) was added to the microsphere suspension and vortexed, and $10 \mu \mathrm{L}$ of EDC solution (10 mg EDC per $2 \mathrm{~mL}$ activation buffer) was added to the solution and vortexed. The beads were incubated for $20 \mathrm{~min}$ in the dark at room temperature. The activated microspheres were centrifuged and the supernatant aspirated. The pellet was resuspended in $250 \mu \mathrm{L}$ of coupling buffer, centrifuged and supernatant aspirated. The step was repeated. 
Each specific bead set was resuspended with $250 \mu \mathrm{L}(100 \mu \mathrm{g} / \mathrm{mL})$ of its assigned antigen preparation. The solutions were incubated at room temperature for $1 \mathrm{~h}$ to mix and then washed twice. After the second wash cycle, $250 \mu \mathrm{L}$ of phosphate-buffered saline of $\mathrm{pH} 7.4$, $1 \%$ bovine serum albumin and $0.05 \%$ sodium azide (PBSBN) was added. The tube was incubated for $30 \mathrm{~min}$ in the dark at room temperature. After incubation, centrifugation and removal of the supernatant, the pellet was resuspended in $100 \mu \mathrm{L}$ of PBSBN. The concentration of conjugated beads in each set was enumerated by a hemocytometer. The bead sets were kept at $4^{\circ} \mathrm{C}$ in the dark until needed.

\section{Master bead mix}

The master bead mix containing the bead sets coupled to the proteins of interest was mixed to ensure the total concentration of beads was 68 beads/ $\mu \mathrm{L}$. Based on the volume of the master bead mix required, each individual bead set was added to achieve the desired final concentration in PBSBN.

\section{Plate preparation}

The wells of a filter plate were prewetted with $100 \mu \mathrm{L}$ of Bio-Plex Assay Buffer (Bio-Rad Laboratories) and vacuum dried. The master bead mix was vortexed and sonicated for $2 \mathrm{~min}$. One hundred microlitres of master bead mix were pipetted into each well followed by vacuum removal. The wells were washed twice with $100 \mu \mathrm{L}$ of Bio-Plex Wash Buffer (BioRad Laboratories) and vacuumed. The serum samples were diluted to $10^{-1}, 10^{-2}, 10^{-3}$ and $10^{-4}$ concentration with PBSBN. One hundred microlitres of sample for each dilution and a duplicate were added to the wells. The plate was covered and placed on a shaker to incubate for $30 \mathrm{~min}$ at room temperature. The wells were then vacuum dried and washed three times with Bio-Plex Wash Buffer.

\section{Secondary biotinylated detection antibody}

One hundred microlitres at a concentration of $0.5 \mathrm{mg} / \mathrm{mL}$ of detection antibody (Mouse Anti-Human IgA $\mathrm{A}_{1}$-Biot) (1:400 PBSBN) was added to each well. The plate was covered, incubated and shaken at room temperature for $30 \mathrm{~min}$. Following incubation, the wells were vacuum dried and washed three times with Bio-Plex Wash Buffer.

\section{Reporter antibody}

One hundred microlitres of Bio-Plex Streptavidin-PE (Bio-Rad Laboratories), $1 \mathrm{mg} / \mathrm{mL}$ (1:500 PBSBN), was added to each well. The plate was covered and incubated on a shaker at room temperature for 10 min. Following incubation, the wells were vacuum dried and washed three times with Bio-Plex Wash Buffer. One hundred twentyfive microlitres of Bio-Plex Assay Buffer was used to resuspend the samples. The plate was covered on a shaker for $20 \mathrm{~min}$. The samples were then transferred from the filter plate to a flat-bottom 96-well plate just before analysis.

\section{Plate analysis}

Before each plate calibration and validation, beads (Bio-Rad Laboratories) were used to ensure quality control. The flat-bottom 96-well plate was run on the Bio-Plex Protein Array System (Bio-Rad Laboratories) using Luminex xMap technology. The system was managed with Bio-Plex Manager 4.0 software (Bio-Rad Laboratories).

\section{Titration curve}

Serum samples were run at $10^{-1}, 10^{-2}, 10^{-3}, 10^{-4}$ and $10^{-5}$ to determine the optimal dilution for the detection of $\operatorname{Ig} \mathrm{A}_{1}$ and $\operatorname{IgG}_{1}$ responses.

\section{Controls}

Quality control using Bio-Rad calibration and validation kits was performed before every plate run. As a positive control, a bead coupled to p24 with a known HIV-positive serum sample was used. The negative controls included beads incubated with phosphatebuffered saline only; uncoupled beads were included in the master mix and, thus, tested with each sample.

\section{RESULTS}

\section{Titration curve}

Titration data indicated that $10^{-3}$ was optimal for $\operatorname{Ig} \mathrm{A}_{1}$ detection and $10^{-4}$ for $\operatorname{IgG}_{1}$. This concentration allows for quantitation of $\operatorname{IgA}_{1}$ and $\mathrm{IgG}_{1}$ by avoiding the saturation of response seen at higher concentrations. Figure 2 depicts the titration curves for $\operatorname{IgA}_{1}$ and $\operatorname{IgG}_{1}$.

\section{Serum assay}

Statistically significant differences in $\operatorname{IgA}_{1}$ exist between the serum samples from Winnipeg donors and those from Kenyan donors. Data were compared using an unpaired $t$ test with Welch's correction for samples with unequal variances. The Winnipeg donors had higher mean fluorescence intensities (MFI) with significant $\mathrm{P}$ values for anti-HAIgA $\mathrm{A}_{1}$ to A/Wyoming/3/2003 $(\mathrm{P}=0.044)$, A/Vietnam/1203/2004 $(\mathrm{P}=0.0179), \mathrm{A} / \mathrm{New}$ Caledonia/20/99 $(\mathrm{P}<0.0001)$ and $\mathrm{B} /$ Tokyo/53/99 $(\mathrm{P}=0.0002)$ (Figure 3). No significant differences were seen between the groups in their response to B/Jilin/20/2003.

$\mathrm{IgG}_{1}$ from Winnipeg donors and those from Kenyan donors were also compared. Data were compared using an unpaired $t$ test with Welch's correction for samples with unequal variances. The Winnipeg donors had higher MFI with significant $\mathrm{P}$ values for $\mathrm{A} / \mathrm{Wyoming}, \mathrm{B} /$ Tokyo and $\mathrm{B} / \mathrm{Jilin}(\mathrm{P}=0.0135, \mathrm{P}=0.006, \mathrm{P}=0.026$, respectively $)$ (Figure 4).

The results of $\mathrm{IgG}_{1}$ MBA to HIA were compared in a subset of individuals. When an MFI threshold of 500 was compared with an HIA titre of greater than 40 , the agreement between the assays was $70 \%$. The HIA titre was greater than 40 in $10 \%$ of MBA-negative individuals and, conversely, an MBA of greater than 500 MFI was detected in $10 \%$ of HIA-negative individuals.

\section{DISCUSSION}

MBA analysis has several benefits over traditional HIA methodology for the detection of anti-influenza IgA $\mathrm{A}_{1}$ and $\operatorname{IgG}_{1}$. By simultaneously assaying for different type-specific anti-influenza $\operatorname{Ig} \mathrm{A}_{1}$ and $\operatorname{IgG}_{1}$, a full influenza workup can be performed on a small sample volume. This high-throughput capability is necessary for rapid identification of influenza strains during an epidemic. Second, the ability of MBA to simultaneously assay for multiple antiflu antibodies is invaluable for measuring vaccine response toward the vaccine strains and assessing cross-response to strains not included in the vaccine formulation. Another advantage of this flexible platform is the ability to couple different fragments of influenza proteins, thus enabling the detection of more specific targets within these proteins. The usefulness of the assay for seroepidemiology was demonstrated by the data presented. This semiquantitative measure allows for better characterization of the antibody response to multiple influenza strains simultaneously, and determination of different Ig classes by the use of diverse secondary antibodies.

Observed differences in $\operatorname{IgG}_{1}$ and $\operatorname{IgA}_{1}$ antibody responses to influenza antigens may be due to several factors. Circulating strains of influenza can vary geographically, creating different antibody profiles among distinct populations. Another possibility is that because Kenya does not have an influenza immunization program equivalent to the one in Canada, the Kenyan population does not have the exposure that vaccinations afford. As expected, the response to A/ New Caledonia/20/99 was significantly higher in the Winnipeg population. The finding is probably the result of this strain circulating in the community and being a part of the trivalent vaccine for the past six years in North America. Winnipeg donors also showed higher levels to $\mathrm{B} /$ Tokyo/53/99, but no difference in B/Jilin/20/2003. Again, this can be explained by the belief that although type $\mathrm{B}$ viruses have circulated in Kenya, the expected higher responses by Kenyan donors were offset and even exceeded by the vaccination programs in Canada.

Unexpectedly, a response by Winnipeg donors to A/Vietnam/ 1203/2004 (avian flu) without any illness suggests that current vaccination programs may confer some heterotypic immunity. It has 


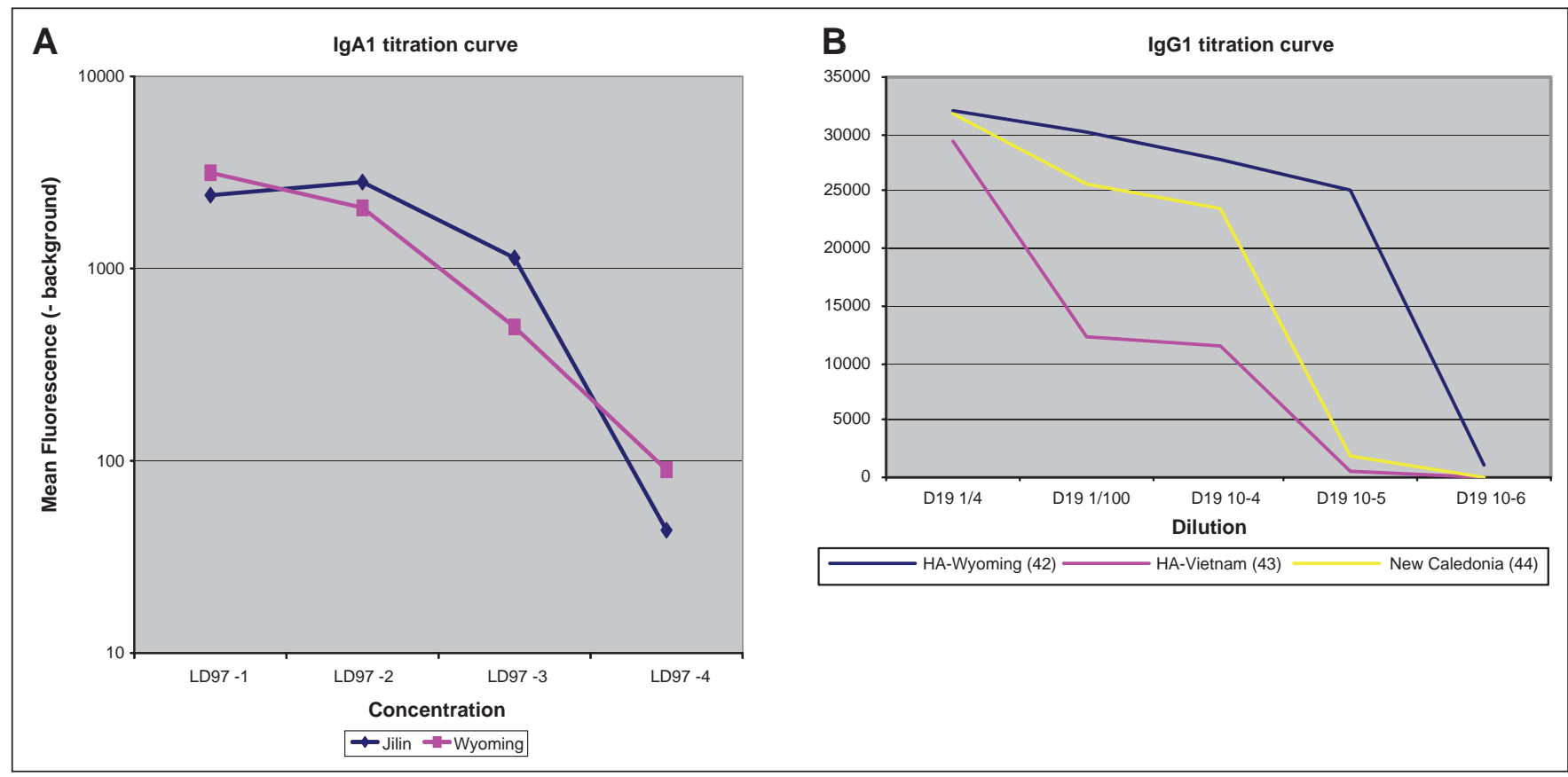

Figure 2) A Immunoglobulin (Ig) A titration curve of Winnipeg donor (D97) responses to influenza hemagglutinin (HA) antigens Jilin (B) and Wyoming (H3N2). B IgG 1 titration curve of Winnipeg donor (D19) responses to influenza HA antigens Wyoming, Vietnam and New Caledonia

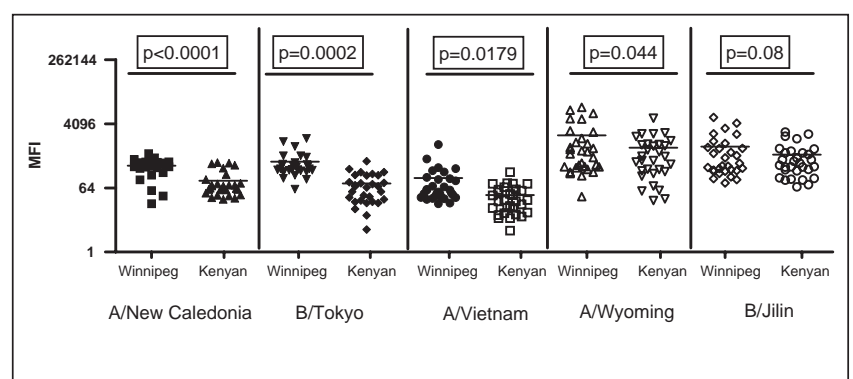

Figure 3) Significant differences in immunoglobulin $A_{1}$ response to influenza antigens as measured by mean fluorescence intensity (MFI)

been noted that pre-existing $\operatorname{IgA}$ to one type of influenza can crossreact with other types of virus much more strongly than IgG. This may be due to the dimeric nature of secretory IgA found in the respiratory epithelium $(13,14)$. These factors may explain the cross-reactions seen with the $\mathrm{H} 5 \mathrm{~N} 1$ virus.

The limitation of the present study is the lack of correlation with clinical protection from influenza-like illness.

\section{CONCLUSIONS}

Serum $\operatorname{Ig} \mathrm{A}_{1}$ and $\operatorname{IgG}_{1}$ antibodies specific for influenza antigens were successfully detected using this method. Significant differences in the amount of flu-specific $\operatorname{Ig} \mathrm{A}_{1}$ and $\operatorname{IgG}_{1}$ antibodies were demonstrated between Winnipeg and Kenyan donors, reflecting geographical differences and the lack of influenza immunization in Kenya.

MBA analysis is a relatively quick and cost-effective method for serum antibody analysis. The potential to simultaneously assay small sample volumes for a multitude of antigens makes this method invaluable for the study of influenza epidemiology and, potentially, other infectious agents, as well as for monitoring vaccine response. The rapid detection of anti-influenza $\operatorname{Ig} \mathrm{A}_{1}$ can be diagnostic of recent infection. Although correlation with HIA titres and protection from clinical illness caused by influenza would be important to establish, the assay

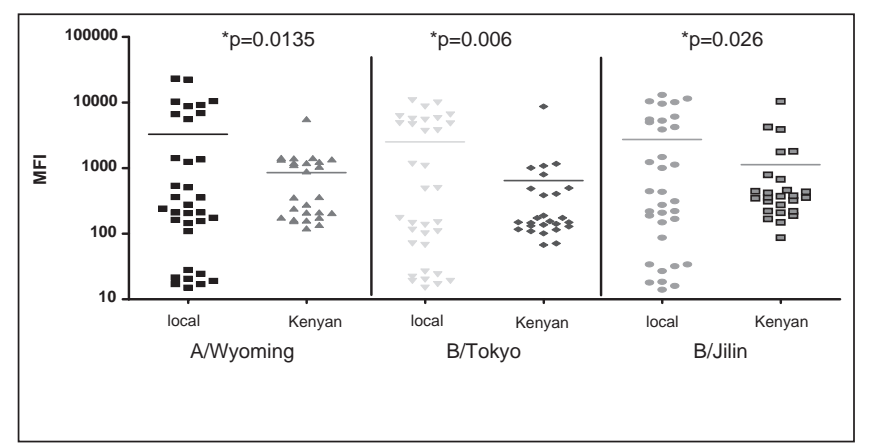

Figure 4) Significant differences (denoted by asterisks) in immunoglobulin $G_{1}$ response to flu antigens as measured by mean fluorescence intensity (MFI)

may be useful in assessing the extent to which a population has been exposed to a specific strain and may assist in targeting preventive interventions to nonimmune populations.

ACKNOWLEDGEMENTS: The authors thank Catherine Card, Paul McLaren, Sandy Koesters, Judy Lawrence, Conar O'Neil, The University of Manitoba and The Gates Grand Challenges in Global Health.

\section{REFERENCES}

1. Doherty PC, Turner SJ, Webby RG, Thomas PG. Influenza and the challenge for immunology. Nat Immunol 2006;7:449-55.

2. Nicholson KG, Wood JM, Zambon M. Influenza. Lancet 2003;362:1733-45.

3. Cox RJ, Brokstad KA, Ogra P. Influenza virus: Immunity and vaccination strategies. Comparison of the immune response to inactivated and live, attenuated influenza vaccines.

Scand J Immunol 2004;59:1-15. 
4. Levinson W. Medical Microbiology \& Immunology, 8th edn. Toronto: McGraw Hill, 2004.

5. Tamura S, Kurata T. Defense mechanisms against influenza virus infection in the respiratory tract mucosa. Jpn J Infect Dis 2004;57:236-47.

6. Jeon SH, Ben-Yedidia T, Arnon R. Intranasal immunization with synthetic recombinant vaccine containing multiple epitopes of influenza virus. Vaccine 2002;20:2772-80.

7. Rothbarth PH, Groen J, Bohnen AM, de Groot R, Osterhaus AD Influenza virus serology - a comparative study. J Virol Methods 1999;78:163-9.

8. Pickering JW, Martins TB, Schroder MC, Hill HR. Comparison of a multiplex flow cytometric assay with enzyme-linked immunosorbent assay for quantitation of antibodies to tetanus, diphtheria, and Haemophilus influenzae Type b. Clin Diagn Lab Immunol 2002;9:872-6.
9. Morgan E, Varro R, Sepulveda H, et al. Cytometric bead array: A multiplexed assay platform with applications in various areas of biology. Clin Immunol 2004;110:252-66.

10. Elshal MF, McCoy JP. Multiplex bead array assays: Performance evaluation and comparison of sensitivity to ELISA. Methods 2006;38:317-23.

11. WHO influenza update. <www.who.int/csr/don/2009_07_06/en/ index.html $>$ (Accessed on June 2, 2010).

12. Public Health Agency of Canada. Cases of Pandemic (H1N1) 2009 virus in Canada. <www.phac-aspc.gc.ca/alert-alerte/swine-porcine/ surveillance> (Accessed on June 2, 2010).

13. Asahi-Ozaki Y, Yoshikawa T, Iwakura Y, et al. Secretory IgA antibodies provide cross-protection against infection with different strains of influenza B virus. J Med Virol 2004;74:328-35.

14. Tamura S, Tanimoto T, Kurata T. Mechanisms of broad cross-protection provided by influenza virus infection and their application to vaccines. Jpn J Infect Dis 2005;58:195-207. 


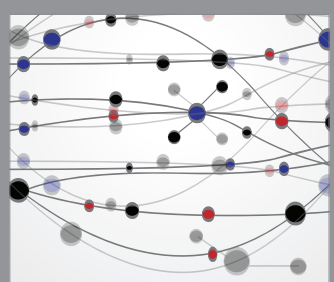

The Scientific World Journal
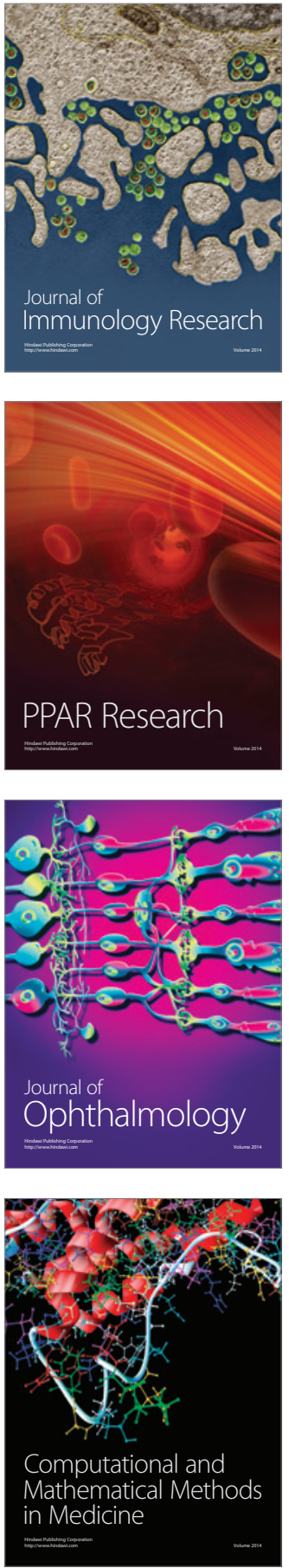

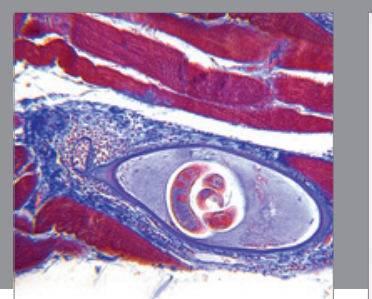

Gastroenterology Research and Practice

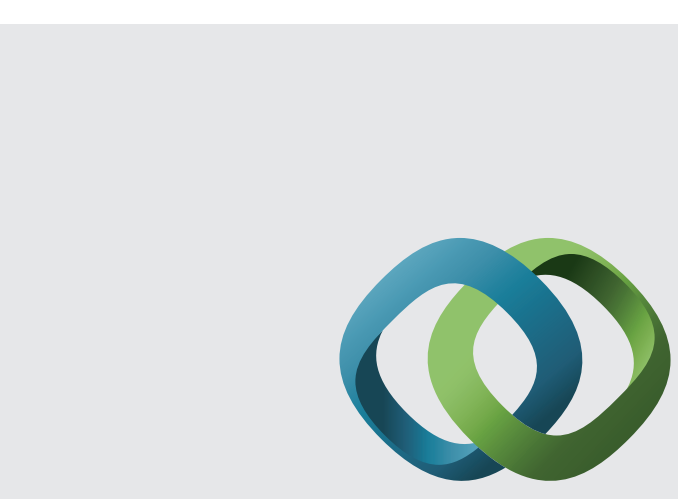

\section{Hindawi}

Submit your manuscripts at

http://www.hindawi.com
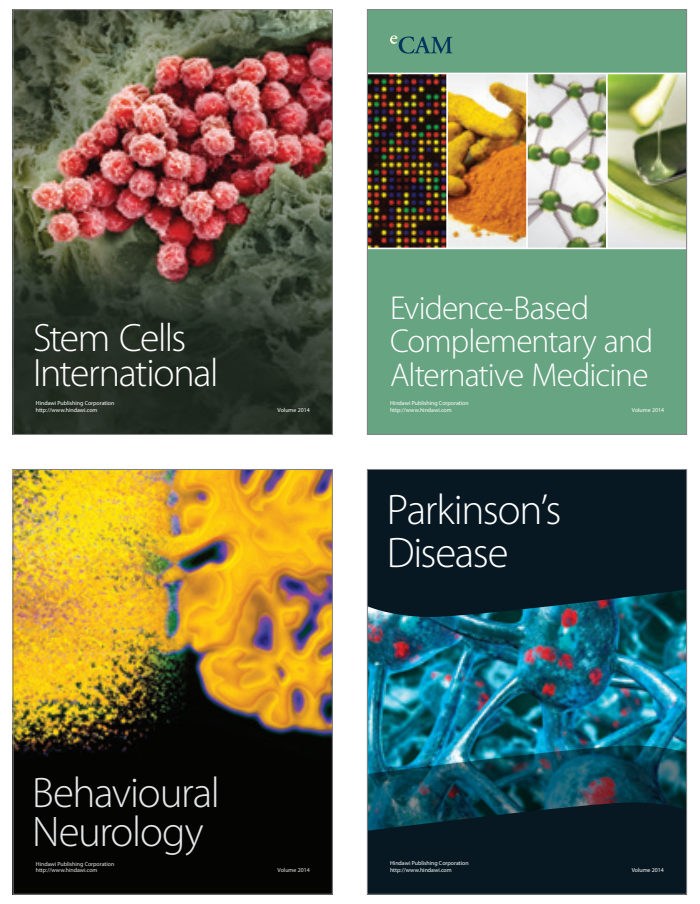
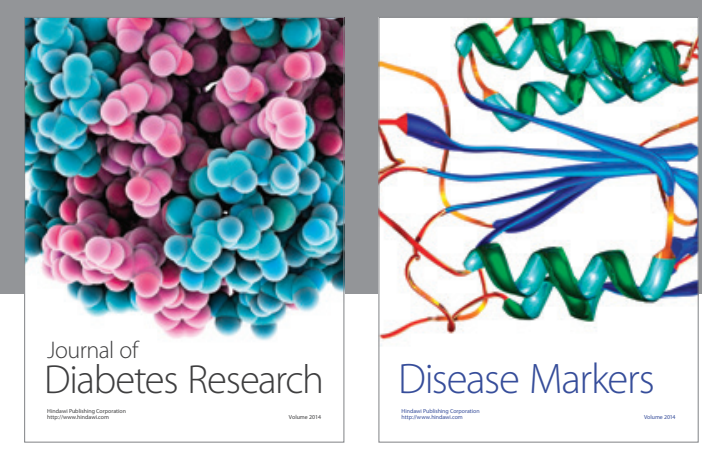

Disease Markers
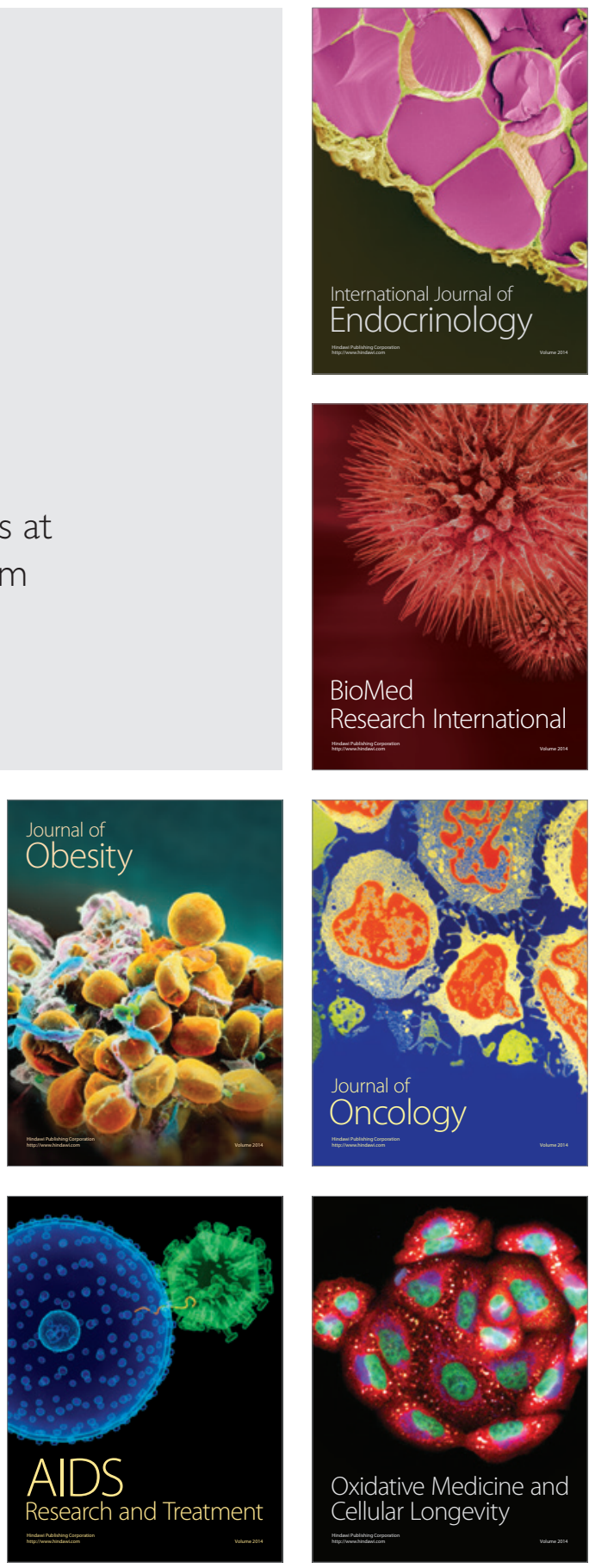